\title{
Termal ve Kimyasal Önişlemlerin Atıksu Çamuru ve Şeker Pancarı Küspesi Karışımından Biyogaz Eldesindeki Etkilerinin Belirlenmesi
}

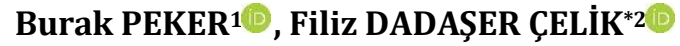 \\ 1,2Erciyes Üniversitesi, Mühendislik Fakültesi, Çevre Müh. Bölümü, 38280, Kayseri, Türkiye
}

(Alınıș / Received: 05.12.2018, Kabul / Accepted: 06.11.2019, Online Yayınlanma / Published Online: 30.12.2019)

\section{Anahtar Kelimeler}

Biyogaz,

Kimyasal önişlem,

Termal önişlem,

Şeker pancarı küspesi,

Arıtma çamuru
Özet: Bu çalıșmada, evsel atık suların arıtılması sonrası olușan arıtma çamuru ve șeker fabrikalarından atık olarak çıkan şeker pancarı küspesi kullanılarak biyogaz üretim düzeyleri incelenmiştir. Bu maddelerden biyogaz üretim veriminin arttırılması için termal ve kimyasal önişlemlerin etkileri değerlendirilmiştir. Çalışmada 30 gün süreyle mezofilik şartlarda anaerobik işlem uygulanmış, biyogaz üretim düzeyleri ve biyogaz içindeki metan oranları ölçülmüştür. Önişlem uygulanmamış şeker pancarı küspesinden metan üretim düzeyleri $84 \mathrm{~L} / \mathrm{kg}$ UKM (uçucu katı madde) olarak gerçekleşirken, önişlem uygulanmamış arıtma çamuru $67 \mathrm{~L} / \mathrm{kg}$ UKM düzeyinde metan üretmiștir. Şeker pancarı küspesi ve arıtma çamuru birlikte hammadde olarak kullanıldığında ise metan üretim düzeyi $103 \mathrm{~L} / \mathrm{kg}$ UKM olarak gerçekleşmiştir. Şeker pancarı küspesi ve arıtma çamuru karışımlarına termal ve kimyasal $\left(\mathrm{O}_{3}\right.$ ve $\left.\mathrm{NaOH}\right)$ ön işlemler uygulanmıştır. Termal ön işlemli karışımın metan üretim düzeyi $116 \mathrm{~L} / \mathrm{kg} \mathrm{UKM}, \mathrm{NaOH}$ ile önişlem uygulanmış karıșımın metan üretim düzeyi $99 \mathrm{~L} / \mathrm{kg}$ UKM ve ozon ile önişlem uygulanmış karışımın metan üretim düzeyi ise $133 \mathrm{~L} / \mathrm{kg}$ UKM olarak gerçekleşmiştir. Sonuç olarak, kimyasal ve termal önişlemlerin atıklardan biyogaz eldesini arttırdığı tespit edilmiştir. Hammaddelere uygulanan önişlemler organik maddenin daha kolay bozunabilir hale gelmesini sağlamış, böylece daha yüksek biyogaz üretimi gerçekleşmiştir.

\section{Determination of the Effects of Thermal and Chemical Pretreatment on Biogas Production from Sewage Sludge and Sugar Beet Pulp}

\section{Keywords}

Biogas,

Chemical pretreatment, Thermal pretreatment, Sugar beet pulp, Wastewater sludge

\begin{abstract}
In this study, biogas production from sugar beet pulp and sewage sludge was examined. In order to increase the efficiency of biogas production from these materials, the effects of thermal and chemical pretreatments were evaluated. During the study, anaerobic treatment was carried out under mesophilic condition for 30 days. Biogas production levels and methane contents in biogas were measured daily. The sewage sludge produced methane at the level of $67 \mathrm{~L} / \mathrm{kg}$ VS (volatile solids) without pretreatment, while the methane production from the sugar beet pulp without pretreatment was $84 \mathrm{~L} / \mathrm{kg}$ VS. When sugar beet pulp and wastewater sludge were used together as raw materials, the production level of methane was $103 \mathrm{~L} / \mathrm{kg} \mathrm{VS}$. Thermal and chemical $\left(\mathrm{O}_{3}\right.$ and $\left.\mathrm{NaOH}\right)$ pretreatments were applied to sugar beet pulp and sewage sludge mixtures. The methane production level of the mixture with thermal pretreatment was $116 \mathrm{~L} / \mathrm{kg} \mathrm{VS}$, the methane production level with basic pretreatment with $\mathrm{NaOH}$ was $99 \mathrm{~L} / \mathrm{kg}$ VS and the methane production level of the mixture subjected to ozone pretreatment was $133 \mathrm{~L} / \mathrm{kg}$ VS. As a result, chemical and thermal pretreatments were found to increase biogas production from waste materials. Pretreatments applied to raw materials converted the organic material to more degradable forms and higher biogas yields were obtained.
\end{abstract}

\section{Giriş}

Artan enerji ihtiyacı ve tükenmekte olan fosil yakıtlar yenilenebilir enerjiye olan ilgiyi arttırmıștır. Enerji günümüzde büyük oranda fosil yakıtlardan sağlansa da, gelecekte yenilenebilir enerji kaynaklarına yönelmek bir gereklilik haline gelecektir. $\mathrm{Bu}$ enerji kaynaklarından biri de biyogazdır.

Biyogaz organik maddelerin mikroorganizmalar tarafindan havasız ortamda parçalanması sonucu ortaya çıkan, bileşiminde \%50-\%80 metan $\left(\mathrm{CH}_{4}\right)$ ve 
\%20-\%50 karbondioksit $\left(\mathrm{CO}_{2}\right)$ ve eser miktarda hidrojen sülfür $\left(\mathrm{H}_{2} \mathrm{~S}\right)$, hidrojen $\left(\mathrm{H}_{2}\right)$, karbon monoksit (CO), ve azot $\left(\mathrm{N}_{2}\right)$ bulunduran, yanıcı bir biyolojik süreç ürünüdür [1,2]. Biyogaz üretimi üç aşamada gerçekleşir [3]. Birinci aşama olan hidrolizde karmaşık yapılı organik maddeler (karbonhidrat, protein, yağlar) enzimler yardımıyla bakteriler tarafından basit şekerler, gliserin, amino asit, yağ asitleri ve çözülebilir uçucu organik maddelere dönüştürülür. İkinci aşama olan asit üretimi aşamasında asetojenik bakteri grupları tarafından hidroliz sonucu açığa çıkan uçucu organik maddeler karbondioksit, asetik asit, uçucu yağ asitleri ve hidrojene dönüştürülür. Son aşama olan metan üretimi aşamasında ise $\mathrm{CH}_{4}$ oluşturan bakteriler tarafından $\mathrm{CO}_{2}$ ve $\mathrm{H}_{2}$ ve asetik asit kullanılarak $\mathrm{CH}_{4}$ ve $\mathrm{CO}_{2}$ oluşturulmaktadırlar.

Biyogaz üretiminde çeşitli organik maddeler (hububat atıkları, misır, şeker pancarı yaprakları, yabani otlar, organik yapılı katı atıklar, hayvansal atıklar ve arıtma çamurları gibi) kullanılmaktadır [4, 5]. Evsel nitelikli arıtma çamuru bu malzemeler arasında hakkında en fazla çalışma yapılan maddeler arasındadır. Evsel arıtma çamurlarından biyogaz üretim düzeyleri, optimum ișletme koşulları, biyogaz üretim düzeylerini artırmak için yapılacak işlemler hakkında çalışmalar literatürde mevcuttur [6, 7]. Şeker pancarı atıkları ise biyogaz üretiminde son yıllarda ilgi çekmeye başlamıştır ve yapılan çalışmalar sınırlı sayıdadır [8-12]. Bu çalışmada evsel atıksu arıtımından kaynaklanan arıtma çamurları ve şeker pancarı endüstrisi atıkları ve bu atıkların birlikte arıtılabilirliği konu edilmektedir. Arıtma çamuru ve şeker pancarı küspesinin bertarafı ve ekonomik fayda sağlamak için kullanılması son derece önemlidir. Halen pek çok işletmede şeker pancarı küspesi ucuz fiyata hayvancılık yapan kişi ve kurumlara satilmakta ve fazlasının bertaraf edilmesi bir maliyet ve çevresel kirlilik oluşturmaktadır. Arıtma çamuru ve biyogaz karışımının biyogaz üretiminde kullanılması hem arıtma çamurlarının hem de şeker pancarı atıklarının ekonomik değeri yüksek olacak şekilde bertaraf edilmesini sağlayacaktır.

Daha önce yapılan pek çok çalışmada farklı maddelerin birlikte kullanımının biyogaz üretimleri üzerinde olumlu etki oluşturduğu gösterilmiștir [1314]. Bunun yanı sıra metan üretim verimlerinin arttırılması için bazı önişlemler uygulanabilmektedir $[15,16,17]$. Önişlemler fiziksel/mekanik önişlemler, biyolojik önişlemler, kimyasal önişlemler ve termal önişlemler olmak üzere dört ana başlık altında toplanabilir [17, 18, 19]. Fiziksel/mekanik önişlemler maddelerin fiziksel yapısını değiştirme özelliğine sahip olup, ultrases, yüksek basınçlı homojenizasyon gibi teknikleri içerirler. Biyolojik önişlemler biyolojik aktivitelerle (örneğin enzimler kullanılarak) maddelerin bozunabilirliğinin arttırılması esasına dayanır. Kimyasal önişlemlerde, karmaşık yapılı organik maddelerin parçalanması için kuvvetli mineral asit veya baz veya ozon $\left(\mathrm{O}_{3}\right)$ kullanılmaktadır. $\quad 60-180 \quad{ }^{\circ} \mathrm{C}$ sıcaklıklarda gerçekleştirilen termal ön işlemler, hücre duvarlarını parçalayarak, mikroorganizmalarca maddenin daha kolay kullanılabilir hale gelmesini sağlamaktadır. Önişleme uğramış maddelerin anaerobik çürümesi, karmaşık yapıdaki organik maddenin parçalanması sebebiyle daha iyi bir stabilizasyona imkân sağlamakta ve bu işlem sonrasında atık miktarı klasik anaerobik çürüme işlemi ile karşılaştırıldığında \%3040 oranında azaltılabilmektedir.

Bu çalışmanın iki temel amacı bulunmaktadır. Birinci amaç arıtma çamuru ve şeker pancarı küspesi karışımından biyogaz üretim potansiyelinin araştırılmasıdır. İkinci amaç ise arıtma çamuru ve şeker pancarı küspesi karışımından biyogaz üretimde termal ve kimyasal önişlemlerin etkilerinin belirlenmesidir. Çalışmada bazik (sodyum hidroksit$\mathrm{NaOH}$ ) ve ozon kimyasal önişlemleri ve termal önişlemlerin etkileri araştırılmaktadır.

Yukarıda sıralana çalışmalar göz önüne alındığında şeker pancarı küspesi ve arıtma çamurları biyogaz üretim potansiyeli oldukça yüksek iki hammaddedir. Bu maddelerle biyogaz üretimi yapılması Türkiye'de birçok ilde büyük şeker fabrikalardan atık olarak çıkan şeker pancarı küspesi ve arıtma tesislerinde en yüksek maliyete neden olan arıtma çamuru bertarafına çözüm sunacaktır. Bu çalışma sayesinde şeker fabrikalarında biyogaz üretim tesisleri kurularak atıkların azaltılması ve geri kazanımının uygulanabilirliği gösterilebilir. Ayrıca fabrikaların atıksu arıtma tesislerinde oluşan arıtma çamurlarından bu sistemle materyal ve enerji kazanımı sağlanabilir.

\section{Materyal ve Metot}

Çalışma dört aşamada tamamlanmıştır. Bu aşamalar, çalışmada kullanılacak maddelerin karakterizasyonunun yapılması, önişlemlerin uygulanması, reaktörlerin kurulması ve izlenmesi ve sonuçların değerlendirilmesi olarak sıralanabilir. Aşağıda aşamalar ayrıntılı olarak açıklanmaktadır.

\section{1. Çalışmada kullanılan maddelerin karakterizasyonu}

Çalışmada kullanılan şeker pancarı küspesi Kayseri Şeker Fabrikası'ndan temin edilmiştir. Arıtma çamuru ve aşı maddesi Kayseri Su ve Kanalizasyon İdaresi tarafından işletilen atık su arıtma tesisinin aktif olarak biyogaz üretiminin yapıldığı anaerobik çürütme reaktöründen alınmıştır. Anaerobik çürütücüye beslenen çamur ön ve son çökeltme tanklarından sağlanmakta olup, sistem mezofilik koşullarda $\left(37-38^{\circ} \mathrm{C}\right)$ çalışmaktadır. Maddelerin karakterizasyonu amaciyla yapılan analizler toplam katı madde (KM), toplam uçucu katı madde (UKM), $\mathrm{pH}$ ve elemental analizi $(\mathrm{C}, \mathrm{N}$ ) içermektedir (Tablo 1). 
$\mathrm{Bu}$ analizlerle biyogaz üretiminde etkili olan besin/aşı oranı, $\mathrm{C} / \mathrm{N}$ oranı, pH, katı madde oranı gibi özellikleri belirlenmiștir. Biyogaz üretimine olumlu etki yaptı̆̆ı önceki çalışmalarda belirlenen bazal besin maddesi reaktörlere eklenmiștir [20].

\section{2. Önişlemlerin uygulanması}

Çalışmanın kapsamında organik maddelere termal ve kimyasal ön işlemler uygulanmıştır. Önişlemler öncesinde arıtma çamuru ve şeker pancarı küspesi kullanılarak \%4 katı madde içeriğine sahip bir karışım hazırlanmıştır. Anaerobik sistemlerde maksimum biyogaz üretim veriminin reaktöre verilen hammaddedeki kat madde derişiminin kütlece \%6 ile \%10 arasında olduğunda gerçekleştiği ve metan üretim verimin, katı madde derişimi \% 12'den fazla olması durumunda ise düştüğü görülmektedir [21]. Farklı bir çalışmada \%4.5 ve \%19.2 aralığında katı madde içeriklerinin etkileri incelenmiș ve katı madde miktarı arttıkça metan veriminin düştüğü gözlenmiştir [22]. Daha önce yemek atıkları ile yapılan bir çalışmada $\% 4, \% 8$ ve $\% 12$ katı madde oranları ile sistem verimi araştırılmış ve \%4 katı madde oranın optimum olduğu tespit edilmiştir [23]. $\mathrm{Bu}$ çalışmada kullanılan arıtma çamurunun katı madde içeriği \%1-2 civarındadır. Buna karșılık șeker pancarı küspesinin sıvı içeriği düşüktür. Uygun koşulları sağlamak için bu çalışmada karıșım \%4 katı madde oranında olacak şekilde hazırlanmıştır.

Termal önişlem yaygın olarak $60-180^{\circ} \mathrm{C}$ arasında yer alan sicaklıklarda uygulanmaktadır [24]. $100^{\circ} \mathrm{C}$ altındaki uygulamalar düşük sıcaklık uygulamaları olarak adlandırılmakta ve daha uzun ișlem süresine ihtiyaç duymaktadır. $100^{\circ} \mathrm{C}$ üzerindeki sıcaklıklarda ise 30-60 dakikalık uygulamalar yeterli olmaktadır [24]. Bu çalışmada yüksek sıcaklık uygulaması tercih edilmiştir. Şeker pancarı küspesi arıtma çamuru karışımına kimyasal madde eklenmeden otoklavda $120^{\circ} \mathrm{C}$ de 2 saat ısıl işlem yapılmıştır.

Kimyasal önişlemde $\mathrm{NaOH}$ ve ozon uygulanmıştır. Daha önce yapılan çalışmalar $[15,16,17,18,19,31]$ incelenmiş ve şeker pancarı küspesi arıtma çamuru karışımının kütlece \%4 katı madde içeren sulu karışımlarına, karışımdaki katı maddenin kütlece \%5'i kadar $\mathrm{NaOH}$ eklenerek oluşturulan 1 litrelik sulu çözeltide 1 gün bekletilerek ön işlem uygulanmıştır. $\mathrm{NaOH}$ ön işlemi sonrası bir $\mathrm{pH}$ ayarlaması yapılmamıştır. Metan üretiminin başlamasıyla ortamdaki pH düştügü için $\mathrm{NaOH}$ ile ön işlem sisteme yüksek pH gibi bir zarar vermemektedir. Ozon ile deaktive olmuş biyokatılar biyolojik parçalanma için çok iyi bir besin kaynağı olmaktadır. Bu biyokatıların anaerobik çürütmede kullanılması çürütme verimini artırmaktadır. Organik madde parçalanma oranı klasik anaerobik çürüme işleminde ortalama \%45 iken $0.06 \mathrm{~g} \mathrm{O}_{3} / \mathrm{g}$ katı madde ozon dozu kullanılarak yapılan önişlem ile ortalama \%65 olmakta, aynı zamanda biyogaz oluşumu da klasik sisteme oranla \%30-40 artış göstermektedir [25]. Ozon önişleminde ise karışımdaki katı madde başına $0.1 \mathrm{~g} \mathrm{O}_{3} / \mathrm{g} \mathrm{KM}$ ozon gazı verilerek önişlem uygulanmıştır.

\subsection{Reaktörlerin kurulması ve işletilmesi}

Çalışmanın üçüncü aşamasında biyogaz üretiminin gerçekleştirileceği reaktör sistemi kurulmuştur. Reaktörler kesikli yapıda çalıştırılmıştır. Şeker pancarı küspesi ve arıtma çamuru, mikroorganizmalar (aşı maddesi) katı madde oranları hesaplandıktan sonra Şekil 1'de gösterilen solda yer alan ve cam şişeler şeklinde planlanmış 1000 ml'lik ağzı tıpalı serum şişelere aktarılmıştır. Ardından azot gazından geçirilerek havasız ortam oluşması sağlanmış ve $37^{\circ} \mathrm{C}$ sıcaklıktaki Binder marka ED 53 model etüvde takibi başlatılmıştır. Biyogaz üretimleri sıvı yer değiștirme prensibiyle belirlenmiştir. Biyogazın içerisindeki $\mathrm{CH}_{4}$ ve $\mathrm{CO}_{2}$ oranları Shimadzu GC-2010 marka gaz kromotografi cihazıyla ölçülmüştür.

Öncelikle şeker pancarı küspesi, arıtma çamuru ve şeker pancarı küspesi+arıtma çamuru için 3'er adet reaktör kurulmuştur. Ardından şeker pancarı küspesi+arıtma çamuru karışımına $\mathrm{NaOH}$, ozon ve termal önişlemeler uygulanmıştır. Ön işlem görmüş numuneler için de 3'er adet reaktör hazırlanmıştır. Bütün reaktörler 30 gün takip edilmiştir.

Tablo 1. Çalıșma kapsamında yapılan analizler ve kullanılan analiz yöntemleri

\begin{tabular}{llll} 
Parametre & $\begin{array}{l}\text { Analiz } \\
\text { Yöntemi }\end{array}$ & $\begin{array}{l}\text { Kullanilan } \\
\text { Teçhizat/Cihaz }\end{array}$ & Marka/Model/Menşei \\
\hline pH & SM 4500H & pH metre & Hach Lange, HQ-40D multimetre, ABD \\
Toplam Katı & SM 2540 G & Desikatör, & Derkimlab, Cam 150 Mm Desikatör, Türkiye, \\
Madde (KM) & & Etüv & Binder, ED 53 Etüv, Almanya \\
Toplam Uçucu & SM 2540 G & Desikatör, & Derkimlab, Cam 150 Mm Desikatör, \\
Katı Madde (UKM) & & Yakma Frrını & Nüve MF 120, Kül Fırını, Türkiye \\
C, N & & Elemental & Leco, TruSpec Micro CHNS, ABD \\
& & Analiz Cihazı & \\
\hline
\end{tabular}




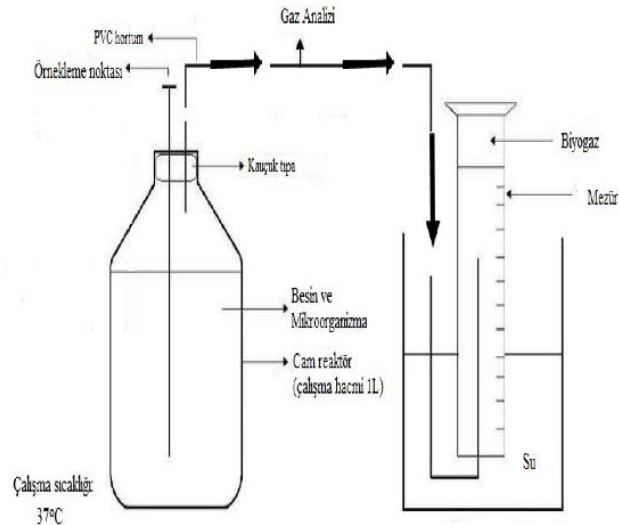

Şekil 1. Reaktör Sistemi

\subsection{Sonuçların değerlendirilmesi}

Her bir reaktöre ait günlük ve toplam metan üretimleri belirlenmiş, bu değerler grafiksel olarak gösterilmiştir. Elde edilen sonuçlar değerlendirilerek şeker pancarı küspesinin, arıtma çamurununi, şeker pancarı küspesi+arıtma çamuru karışımının biyogaz potansiyeli ve önişlem uygulamalarının biyogaz üretimi üzerindeki etkileri değerlendirilmiştir.

\section{Bulgular}

\section{1. Çalışmada kullanılan materyallerin özellikleri}

$\mathrm{Bu}$ çalıșma kapsamında kullanılan şeker pancarı küspesi, arıtma çamuru ve aşının özellikleri Tablo 2 'de sunulmaktadır. Bu değerler kullanılarak katı madde oranı $\% 4$ olacak şekilde reaktörler hazırlanmıștır.

Tablo 2. Kullanılan materyallerin özellikleri

\begin{tabular}{llll}
\hline $\begin{array}{l}\text { Kullanılan } \\
\text { Malzemeler }\end{array}$ & $\begin{array}{l}\text { Şeker } \\
\text { Pancarı } \\
\text { Küspesi }\end{array}$ & $\begin{array}{l}\text { Arıtma } \\
\text { Çamuru }\end{array}$ & Aşı \\
\hline C (\%) & 45 & 39 & 35 \\
N (\%) & 6 & 6 & 6 \\
KM (\%) & 25,8 & 1.1 & 2.7 \\
UKM (\%) & 24.2 & 0.6 & 1.4 \\
Nem (\%) & 74.2 & 98.9 & 97.3 \\
C/N & 13 & 17 & 17 \\
\hline
\end{tabular}

\subsection{Günlük biyogaz üretimi}

Şeker pancarı küspesi, arıtma çamuru ve şeker pancarı küspesi+arıtma çamuru karışımı için günlük biyogaz üretimleri Şekil 2'de sunulmaktadır. Bütün reaktörlerde günlük biyogaz üretimleri 14. günden sonra oldukça düșmüștür. $\mathrm{Bu}$ düșüșün sebebi kullanılan sistemle alakalıdır. Kapalı reaktör sistemi kullanıldığından ortamdaki besin maddesi belli bir süre sonra tükenmekte mikroorganizmalar beslenememekte ve bu nedenle biyogaz üretimi düşmektedir. Belli bir süre daha biyogaz üretiminin olması ortamdaki canlıların ölmesi ve içsel solunumla yani ortamdaki ölen hücrelerle beslenmesiyle açıklanabilir. Biyogaz üretimleri uçucu katı madde (UKM) başına litre şeklinde hesaplanmıştır. Şeker pancarı küspesi, arıtma çamuru ve șeker pancarı küspesi+arıtma çamuru karışımı için günlük ortalama biyogaz üretimleri sırasıyla $12( \pm 10), 8( \pm 7), 14( \pm 9)$ L/kg UKM olarak gerçekleşmiştir. En yüksek günlük biyogaz üretimi arıtma çamurunda $33 \mathrm{~L} / \mathrm{kg}$ UKM olarak gerçekleşmiştir.

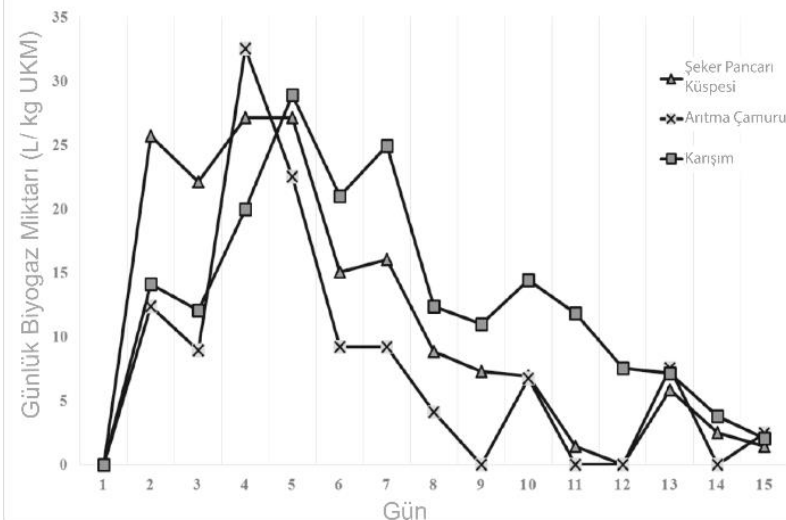

Şekil 2. Şeker pancarı küspesi. arıtma çamuru ve şeker pancarı küspesi +arıtma çamuru karıșımı için günlük biyogaz üretimleri

Şeker pancarı küspesi+arıtma çamuru karışımlarına önişlem uygulanarak günlük biyogaz verimleri değerlendirilmiştir (Şekil 3). Bütün reaktörlerde günlük biyogaz üretimleri 17. güne kadar devam etmiștir. Ozon. Termal, $\mathrm{NaOH}$ ile önişleme tabi tutulmuş olan maddeler için sırasıyla günlük ortalama biyogaz üretimleri 18( \pm 15$), 13( \pm 11)$, 15(士13) L/kg UKM olarak gerçekleşmiştir. En yüksek günlük biyogaz üretimi ozon önişlemi uygulanan reaktörde gerçekleşmiştir (40 L/kg UKM).

Ön işlemli ve ön işlemsiz günlük biyogaz verimleri incelendiğinde, ozon ve $\mathrm{NaOH}$ önişlemlerinin daha yüksek günlük üretime neden oldukları ve gerçekleşen maksimum günlük biyogaz üretiminin de önişlemler sonrasında yükseldiği görülmektedir.

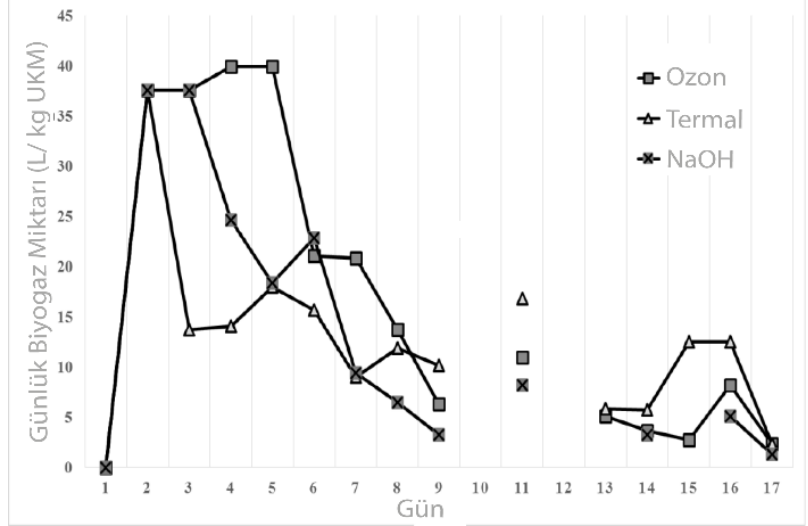

Şekil 3. Termal ve kimyasal önişlemler sonrası șeker pancarı küspesi +arıtma çamuru karıșımı için günlük biyogaz üretimleri 


\subsection{Kümülatif biyogaz üretimi}

Önişlem uygulanmamış ve uygulanmış maddelerin kümülatif toplam biyogaz üretim verimleri belirlenmiştir (Şekil 4 ve Şekil 5). Önişlem uygulanmamış şeker pancarı küspesi, arıtma çamuru ve şeker pancarı küspesi+arıtma çamuru karışımı için toplam biyogaz üretiminin büyük bir kısmı ilk 10 günlük periyotta gerçekleşmiştir. 30 günlük izleme sonunda toplam biyogaz üretimi önişlem uygulanmamış şeker pancarı küspesin de 168( \pm 46$)$ L/kg UKM arıtma çamurunda 116( \pm 34$)$ L/kg UKM ve şeker pancarı küspesi +arıtma çamuru karışımında 191( \pm 68 ) L/kg UKM olarak gözlenmiștir.

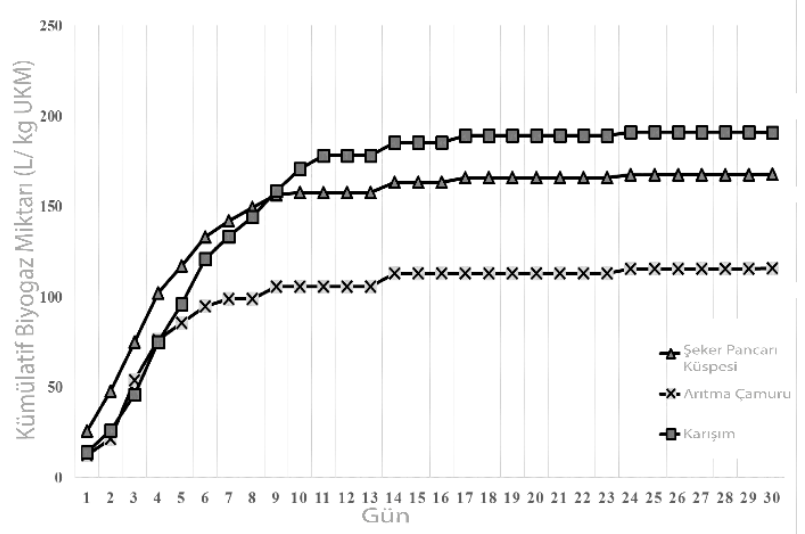

Şekil 4. Şeker pancarı küspesi arıtma çamuru ve şeker pancarı küspesi+arıtma çamuru karışımı için kümülatif biyogaz üretimi

Termal, NaOH ve ozon önişlemi uygulanmış şeker pancarı küspesi+arıtma çamuru karışımı için toplam biyogaz üretiminin sırasıyla $186( \pm 63) \mathrm{L} / \mathrm{kg}$ UKM, $178( \pm 42) \mathrm{L} / \mathrm{kg}$ UKM ve $250( \pm 64) \mathrm{L} / \mathrm{kg}$ UKM olarak gerçekleşmiştir. Özellikle ozon önişlemi ile üretilen biyogaz veriminde önemli ölçüde (yaklaşık \%30) artış gerçekleşmiştir. IBM SPSS programı kullanılarak non-parametrik Wilcoxon Siralama testi uygulanmıştır. $\mathrm{Bu}$ istatiksel analiz \%95 güven aralığında yapılmıștır. Buna göre ozon ve $\mathrm{NaOH}$ ön işlemli reaktör ve karışım reaktörleri arasında anlamlı bir farklılık olduğu tespit edilmiştir. Termal ön işlemli reaktör ve karışım arasında anlamlı bir farklılık bulunmamaktadır.

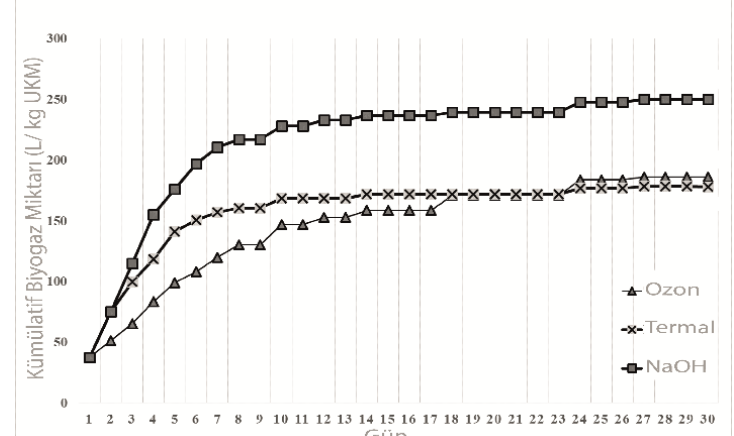

Şekil 5. Termal ve kimyasal önişlemler sonrası şeker pancarı küspesi+arıtma çamuru karıșımı için toplam kümülatif biyogaz üretimi

\subsection{Kümülatif metan üretimi}

Önişlem uygulanmamış ve uygulanmış maddelerin toplam metan üretim verimleri belirlenmiştir (Şekil 6 ve Şekil 7). 30 günlük izleme sonunda şeker pancarı küspesi için $76 \mathrm{~L} \mathrm{CH}_{4} / \mathrm{kg}$ UKM. arıtma çamuru için 68 L $\mathrm{CH}_{4} / \mathrm{kg}$ UKM ve şeker pancarı küspesi+arıtma çamuru karışımı için $98 \mathrm{~L} \mathrm{CH}_{4} / \mathrm{kg}$ UKM metan üretimine ulaşılmıştır.

Termal, $\mathrm{NaOH}$ ve ozon önişlemi uygulanmış şeker pancarı küspesi+arıtma çamuru karışımı için toplam metan üretimi sırasıyla 116( \pm 39$)$ L/kg UKM, 96( \pm 26$)$ $\mathrm{L} / \mathrm{kg}$ UKM ve $133( \pm 38) \mathrm{L} / \mathrm{kg}$ UKM olarak gerçekleşmiştir. Kümülatif toplam biyogazın yaklaşık \%50-\%70'inin metan olduğu görülmüştür. En yüksek metan üretiminin ozon önişlemi uygulandığında oluştuğu görülmüştür. Wilcoxon testine göre Termal ve ozon önişlemli reaktörler arasında p değeri $<0.001$ bulunmuştur. $\mathrm{NaOH}$ ve ozon önişlemli reaktörler arasındaki istatiksel analiz sonucu p değeri $<0.001$ olarak belirlenmiștir. $\mathrm{NaOH}$ ve termal ön işlemli reaktörler arasındaki anlamlılık düzeyi $<0.001$ 'dir. Bulunan bu değerler reaktörler arasında 0.001 düzeyinde için istatiksel olarak anlamlı bir farklılık olduğunu göstermektedir.

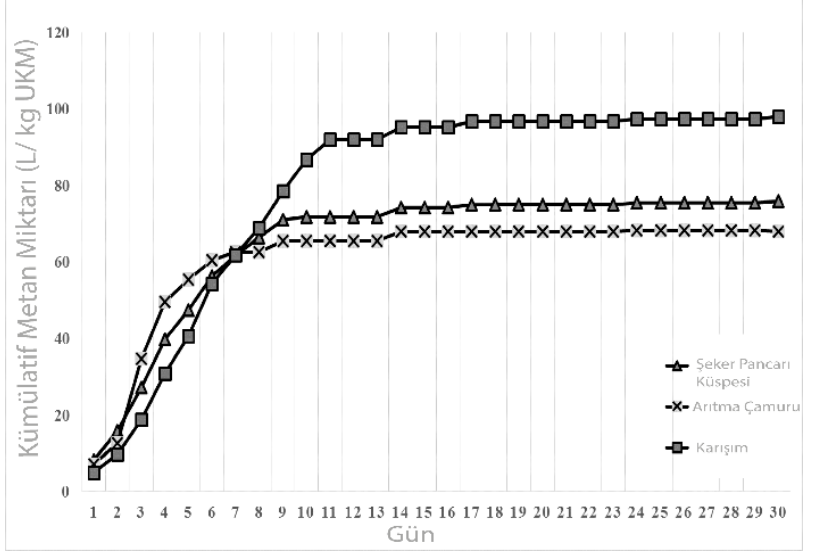

Şekil 6. Şeker pancarı küspesi arıtma çamuru ve șeker pancarı küspesi+arıtma çamuru karışımı için kümülatif toplam metan üretimi

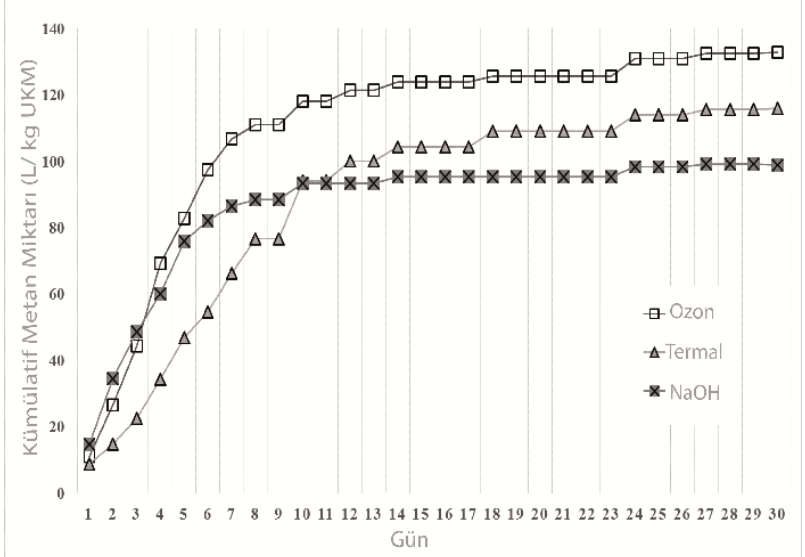

Şekil 7. Termal ve kimyasal önişlemler sonrası şeker pancarı küspesi+arıtma çamuru karışımı için kümülatif toplam metan üretimi 


\section{Tartışma ve Sonuç}

Bu çalışmada şeker pancarı küspesi ve arıtma çamurunun biyogaz üretim potansiyelleri ayrı ayrı ve birlikte kullanılarak incelenmiştir. Ayrıca termal ve kimyasal önişlemlerin şeker pancarı küspesi+arıtma çamuru karışımından biyogaz üretimine etkileri değerlendirilmiştir. Kimyasal önişlem olarak $\mathrm{NaOH}$ ve ozon önişlemleri kullanılmıştır.

Şeker pancarı küspesi ve arıtma çamurunun karıştırılması biyogaz ve metan üretimlerini arttırmıştır. Arıtma çamurunun bitkisel atıklarla karıștırıldığında verimde görülen artış daha önce farklı çalışmalarda da gözlenmiştir. Maragkaki ve diğ. [26] tarafından yapılan çalışmada arıtma çamurunun yemek atıkları, peynir ve zeytin işleme atıkları ile karıștırılmasının biyogaz verimini 1.2-2.7 kat arttırdığı tespit edilmiştir. Park ve diğ. [27] gerçek ölçekli bir çalışmada arıtma çamuru ve meyve ve sebze atıklarının karıștırılmasının biyogaz verimini arttırdığını tespit etmişlerdir. Bu çalışmada da şeker pancarı küspesi ve arıtma çamurunun birlikte kullanılması durumunda metan eldesi arıtma çamuruna göre \%44, şeker pancarı küspesine göre ise $\% 28$ artmıştır.

Kimyasal ve termal önişlemlerin şeker pancarı küspesi+arıtma çamuru karışımına uygulanması biyogaz ve metan üretim verimlerinde değişimlere neden olmuştur. $\mathrm{NaOH}$ ile yapılan önişlem toplam metan verimini \%1 arttırmıştır. Termal önişlem metan veriminde \%18 artışa neden olmuştur. En yüksek değişim ozon önişleminde gözlenmiştir. ozon ile önișlem metan verimini \%35 arttırmıştır. Ön işlemler uygulandıktan sonra biyogaz üretiminin arttığı ve önişlemlerin organik maddelerin parçalanmasını kolaylaştırdığı ve mikroorganizmalar tarafından bu besi maddelerini kolayca tüketilmesine olumlu etki yaptığı görülmektedir. $\mathrm{Bu}$ sebeple uygulanan ön işlemler katı maddelerin sudaki çözünürlüğünü etkileyerek. metan verimini artırmıştır. Ön işlemlerin uygulanması sonrası gerçekleşmiş bir yapısal değişiklik görülmemiştir. Kapalı reaktör ile çalışıldığından ve biyogaz üretimi sonrası tüm reaktörlerde besin maddelerinin tükendiği veya çok küçük parçalar halinde sulu halde bulunduğu görülmüştür.

$\mathrm{NaOH}$, ozon ve termal önişlemlerinin biyogaz üretimi üzerindeki etkilerini değerlendirmek üzere daha önce bazı çalışmalar yapılmıştır. Bazik koşullar hidrolizi hızlandırarak hidrokarbonlar. yağlar ve proteinlerin alifatik polisakkaritler. alifatik asitler ve aminoasitler gibi daha küçük maddelere dönüşümünü sağlamaktadır [16]. $\mathrm{NaOH}$ ile önişlem uygulanmış mısır koçanı mezofilik şartlarda işletilmiş ve $\mathrm{NaOH}$ ön ișleminin biyogaz eldesini ise ortalama \%13.1 ile \%48.3 arasında arttırdığı tespit edilmiştir [28]. Hurma yağı boş meyve demetlerinden biyogaz üretiminin iyileştirilmesinin amaçlandığı çalışmada biyogaz üretimini iyileştirmek için $\mathrm{NaOH}$ ve fosforik asit kullanılarak ön işlem yapılmıştır. Çalışma sonucunda 60 dakika boyunca \%8'lik $\mathrm{NaOH}$ ile ön işlem uygulanması sonucunda biyogaz veriminde \%100 artış gerçekleşmiştir.[29] Neves ve diğ. [30] yaptıkları bazik önişlem çalışmasında metan üretiminde \%89 artış sağlamıştır. Pang ve diğ. [31] yaptığı alkali önişlem ile mısırdan elde edilen metan miktarı \%63 attığı görülmüştür.

Ozon ön işleminin amacı kısmi oksidasyon olup, zor ayrışan bileşiklerin kolay ayrışan bileşiklere dönüştürülmesi hedeflemektedir [32]. Bougrier ve diğ. [33] yaptıkları çalışmada ozonla önişlem uygulamış ve metan üretiminde 2.4 kat artış olduğunu belirlemişlerdir. Dewil ve diğ. [34] tarafından yapılan bir çalışmada, ozonlama ile biyogaz üretiminde yaklaşık 2.5 kat artış olduğu belirlenmiştir.

Termal önişlem yönteminde sıcaklık etkisiyle maddenin bozunabilirliği artmaktadır. Climent ve diğ. [24] çürütülmüş aktif çamurdan termofilik koşullarda $\left(55^{\circ} \mathrm{C}\right)$ biyogaz üretiminde, termofilik önişlemin verimi \%20-\%30 artırdığını belirlemișlerdir.

$\mathrm{Bu}$ çalışmada büyük miktarlarda üretilen ve değerlendirilmeyen arıtma çamuru ve şeker pancarı küspesi değerlendirildiğinde enerji eldesinin mümkün olabileceği saptanmıştır. Şeker pancarı küspesinden biyogaz üretiminin mümkün olduğunu ve arıtma çamurlarının bertarafi büyük bir sorun oluşturduğundan bu iki atığın birlikte kullanılmasıyla daha yüksek biyogaz üretimlerine ulaşılabileceği belirlenmiştir. Ayrıca ileride yapılması planlanan çalışmalarda, biyogaz üretimindeki artış ve ön işlemlerin etkisi araştırılacaktır. Deneysel çalışmalardan elde edilen sonuçlar, anaerobik çürütmede önişlem uygulanarak metan üretim veriminin artırılabileceğini göstermiştir.

\section{Teșekkür}

Bu çalışma TÜBİTAK'ın 2209/A Üniversite Öğrencileri Yurt İçi Araştırma Projeleri Destek Programı kapsamında desteklenmiştir. Katkılarından dolayı TÜBİTAK'a teşekkür ederiz.

\section{Kaynaklar}

[1] Elango, D., Pulikesi, M., Baskaralıngam, P., Ramamurthi, V., Sivanesan, S. 2006. Production of Biogas From Municipal Solid Waste with Domestic Sewage. Journal of Hazardous Materials, 141(2006), 301-304.

[2] Lantz, M., Svensson, M., Bjornsson, L, Börjsson, P. 2006. The Prospects for an Expansion of Biogas Systems in Sweden, Incentives, Barriers and Potentials. Energy Policy 35(2006), 1830-1843

[3] Speece, R.E. 1995. Anaerobik Biotechnology for Industrial Wastewater. Vanderbilt University, Tennessee. 
[4] Mata-Alvarez, J., Macé, S., Llabrés, P. 2000. Anaerobic Digestion Of Organic Solid Wastes. An Overview of Research Achievements And Perspectives. Bioresource Technology 74(1), 316.

[5] Weiland, P. 2010. Biogas Production: Current State and Perspectives. Applied Microbiology and Biotechnology, 85(2010), 849-860.

[6] Kim, J., Park, C., Kim, T-H., Lee, M., Kim, S., Kim, SW., Lee, J. 2003. Effects of Varrious Pretreatments for Enhanced Anaerobic Digestion with Waste Activated Sludge. Journal of Bioscience and Bioengineering, 95(2003), 271-275.

[7] Yeom, I.T., Lee, K.R., Lee, Y.H., Ahn, K.H. and Lee, S.H., 2002. Effects of ozone treatment on the biodegradability of sludge from municipal wastewater treatment plants. Water Science and Technology, 46(4-5), 421-425.

[8] Hutnan, M., Drtil, M., Derco, J., Mrafkova, L., Hornak, M. and Mico, S., 2001. Two-step pilotscale anaerobic treatment of sugar beet pulp. Polish Journal of Environmental Studies, 10(4), 237-244.

[9] Demirel, B. and Scherer, P., 2008. Production of methane from sugar beet silage without manure addition by a single-stage anaerobic digestion process. Biomass and Bioenergy, 32(3), 203209.

[10] Koppar, A. and Pullammanappallil, P., 2008. Single-stage, batch, leach-bed, thermophilic anaerobic digestion of spent sugar beet pulp. Bioresource Technology, 99(8), 2831-2839.

[11] Brooks, L., Parravicini, V., Svardal, K., Kroiss, H., Prendl, L. 2008. Biogas From Sugar Beet Press Pulp as Substitute of Fossil Fuel in Sugar Beet Factories. Water Science and Technology, 58 (2008), 1497-1504.

[12] Fang, C., Boe, K., Angelidaki, I. 2011. Anaerobic Co-Digestion of By-Products From Sugar Production With Cow Manure. Water Research, 45(2011), 3473-3480.

[13] Neves, L., Oliveria, R. and Alves, M. M. 2006. Anaerobic Co-digestion of Coffee Waste and Sewage Sludge. Waste Management, 26(2006), 176-181.

[14] Parawira, W., Murto, M., Zvauya, R., Mattiasson, B. 2004. Anaerobic Batchdigestion of Solid Potato Waste Alone And İn Combination With Sugar Beet Leaves. Renewable Energy, 29(2004), 1811-1823

[15] Nieves, D. C., Karimi, K., Horvath, I.S. 2011. Improvement of Biogas Production From Oil Palm Empty Fruit Bunches (OPEFB). Industrial Crops and Products, 34(2011), 1097-1101.

[16] Ofoefule, A.U., Uzodinm, E.O., Onukwuli, O.D. 2009. Comparative Study of The Effect of
Different Pretreatment Methods On Biogas Yield From Water Hyacinth (Eichhornia Crassipes). International Journal of Physical Sciences, 4(2009), 535-539.

[17] Müller, J.A., Winter, A. and Struenkmann, G., 2004. Investigation and assessment of sludge pre-treatment processes. Water Science and Technology, 49(10), 97-104.

[18] Ariunbaatar, J., Panico, A., Esposito, G., Pirozzi, F., Lens, P. N. L. 2014. Pretreatment Methods To Enhance Anaerobic Digestion of Organic Solid Waste. Applied Energy, 25(2014), 143-156.

[19] Deepanraj B., Sivasubramanian V., Jayaraj S.. 2013. Enhancement of Biogas Production by Pretreatment: A review, IV th International Conference on Advances in Energy Research, Indian Institute of Technology Bombay, Mumbai (2013), 309-319

[20] Angelidaki, I., Alves, M., Bolzonella, D., Borzacconi, L., Campos, J. L., Guwy, A. J., Kalyuzhnyi, S., Jenicek, P., van Lier, J. B. 2009. Defining the Biomethane Potential (BMP) of Solid Organic Wastes and Energy Crops: A Proposed Protocol for Batch Assays. Water Science and Technology, 59 (2009), 927-934.

[21] Desai, M., Patel, V., Madamvar, D. 1994. Effect of Temperature And Retention Time On Biomethanation of Cheese Whey-Poultry WasteCattle Dung. Environmental Pollution, 83(1994), 311-315

[22] Liotta, F., d'Antonio, G., Esposito, G., Fabbricino, M., van Hullebusch, E.D., L. Lens, P. N., Pirozzi, F., Pontoni, L. 2014. Effect Of Total Solids Content on Methane and Volatile Fatty Acid Production in Anaerobic Digestion of Food Waste. Waste Management \& Research, 32(2014), 947-953.

[23] Dadaser-Celik, F., Azgin S. T., Yildiz Y. S. 2016. Optimization Of Solid Content, Carbon/Nitrogen Ratio and Food/Inoculum Ratio for Biogas Production From Food Waste. Waste Management and Research, 34(2016), 12411248

[24] Climent, M., Ferrer, I., Baeza, M., Artola, A., Vazquez, F. and Font, X. 2007. Effects of Thermal and Mechanical Pretreatments of Secondary Sludge on Biogas Production under Thermophilic Conditions. Chemical Engineering Journal, 133(2007), 335-342

[25] Vranitzky, R., Lahnsteiner, J. 2005. Sewage Sludge Disintegration Using Ozone - A Method of Enhancing the Anaerobic Stabilization of Sewage Sludge. VA TECH WABAH, R\&D Process Engineering, Siemensstrasse, Vienna, Austria, 89(2005), 1211.

[26] Maragkaki, A. E., Vasileiadis, I., Fountoulakis, M., Kyriakou, A., Lasaridi, K., Manios, T. 2018. Improving Biogas Production. From Anaerobic 
Co-Digestion of Sewage Sludge With A Thermal Dried Mixture Of Food Waste, Cheese Whey And Olive Mill Wastewater. Waste Management, 71(2018), 644-651.

[27] Park, N. D., Thring, R. W., Garton, R. P., Rutherford, M. P., Helle, S. S. 2011. Increased Biogas Production in A Wastewater Treatment Plant by Anaerobic Co-Digestion of Fruit And Vegetable Waste And Sewer Sludge - A Full Scale Study. Water Science and Technology, 64(2011), 1851-1856.

[28] Li, X., Zheng, M., Fu, G., Lar, J. S. 2009. Anaerobic Co-Digestion of Cattle Manure with Corn Stover Pretreated by Sodium Hydroxide for Efficient Biogas Production, Energy \& Fuels 23(9), 46354639

[29] D.C. Nieves, K. Karimi, I.S. Horvath. 2011. Improvement of Biogas Production From Oil Palm Empty Fruit Bunches (OPEFB). Ind Crops Prod. 34(2011), 1097-1101.
[30] Pang, Y. Z., Liu, Y. P., Li, X. J., Wang, K. S., Yuan, H. R. 2008. Improving Biodegradability and Biogas Production Of Corn Stover Through Sodium Hydroxide Solid State Pretreatment. Energy \& Fuels, 22(2008), 2761-2766.

[31] Perez-Elvira, S. I., Nieto Diez, P., Fdz-Polanco, F., 2006. Sludge Minimisation Technologies. Reviews in Environmental Science and Bio/Technology, 5(2006), 375-398

[32] Bougrier, C., Battimelli, A., Delgenes, J., Carrere, H. 2007. Combined Ozone Pretreatment and Anaerobic Digestion For The Reduction of Biological Sludge Production in Wastewater Treatment. Ozone: Science and Engineering, 29(2007), 201-206.

[33] Dewil, R., Appels, L., Baeyens, J., Degrève, J. 2007. Peroxidation Enhances the Biogas Production in the Anaerobic Digestion of Biosolids. Journal of Hazardous Materials, 31(2007), 577-581. 